Battery electric vehicles: Looking behind to move forward Peer-reviewed author version

SAFARI, Momo (2018) Battery electric vehicles: Looking behind to move forward. In: ENERGY POLICY, 115, p. 54-65.

DOI: 10.1016/j.enpol.2017.12.053

Handle: http://hdl.handle.net/1942/25841 


\title{
Battery electric vehicles: looking behind to move forward
}

\author{
M. Safari ${ }^{1,2}$ \\ 1Institute for Material Research (IMO), Hasselt University, 3590 Diepenbeek, Belgium \\ 2IMEC, division IMOMEC, Wetenschapspark 1, 3590 Diepenbeek, Belgium
}

\begin{abstract}
.
It is getting increasingly crucial for policymakers to acquire reliable price forecasts for battery electric vehicles (BEVs) to make choices and set priorities. Here, we examine the prospects for the wide deployment of BEVs, following an ex-post analysis of their learning rate and an ex-ante forecast of their price up to 2040. We make a clear distinction between the mainstream of BEVs and a hypothetical group of BEVs that are technically on a par with internal combustion vehicles (ICVs). To do so, we introduce a new index, in which the driving range and max-speed of a vehicle are coupled together, i.e., the Mobility-Diffusion coefficient. We highlight different shares of battery packs (i.e., $19 \pm 1 \%$ ), and the ensemble of electrification components (e.g., battery pack, electric motor, power electronics), i.e., electrification cost $(52 \pm 2 \%)$, in the price of a BEV. Our price projections suggest that there is no prospect of breakeven between BEVs and ICVs before 2040 for both groups of BEVs, because the current learning rates of $9 \pm 2 \%$ and $15 \pm 1 \%$ for the price and electrification costs, respectively, of BEVs. Strong and long-term support from policymakers is required to ensure competitiveness of BEVs with ICVs in the near future.
\end{abstract}


Keywords: battery-electric vehicle, learning rate, electrification cost

\section{Introduction}

The competition between battery electric vehicles (BEVs) and internal combustion vehicles (ICV) has a history that is as old as the car industry. Notwithstanding the very low specific energy of batteries (i.e., 10-25 Wh/ kg) in times gone by (i.e., 1890-1911), there was a significant market for BEVs, e.g., in 1899 the number of BEVs registered in US was approximately 1.5 times the number of ICVs (Flink, 1970). The advent of manual-crankfree ICVs in 1912 was a turning point, when development of BEVs dropped off and further advancement in battery technology (i.e., lead-acid batteries) paved the way for rapid diffusion of start-lighting-ignition (SLI) ICVs (Cowan and Hulten, 1996). Limitations in the driving range and performance (speed, aging), together with higher capital costs, still follow BEVs like a shadow. These limitations have been strong enough to impede BEVs from reaching a critical mass in the car market (i.e., in 2015, BEVs and plug-in-hybrid electric vehicles (PHEVs) had a market share of less than $1 \%$ in the US and China) (OECD/IEA, 2016), despite public awareness about the evanescent reserves of fossil fuels and possible room for environmental benefits. Depending on the share of renewables in the electricity mix (REN21, 2015) used to charge BEVs, there might be wide variation in the difference between the well-to-wheel carbon-footprint of BEVs and ICVs (Ramachandran and Stimming, 2015). For example, this difference falls approximately in the ranges of 20-80 and 70-150 $\mathrm{g} \mathrm{CO}_{2}$-e/ $\mathrm{km}$ in the UK and California, respectively. (Ma et al., 2016). 
Without doubt, the current generation of BEVs owes a great deal to Lithium-ion batteries (LIBs). The unprecedented record of practical storage of electrical energy as high as 150 $\mathrm{Wh} / \mathrm{kg}$ at a cell level has been achieved only with the aid of lithium insertion electrodes and non-aqueous electrolytes (Whittingham, 1976; Armand and Tarascon, 2008; Godenough and Park, 2013; Dunn et al., 2011). In the BEVs of today, few hundreds (pouch cell) or thousands (18650 cylindrical cell) of LIB cells, are bundled together in the configuration of few tens of modules and housed inside the battery pack (Blomgren, 2017; Choi and Aurbach, 2016). Such LIB packs are characterized by a gravimetric energy density in the range of 80 to $150 \mathrm{Wh} / \mathrm{kg}$ (Appendix A). Not surprisingly, it is expected that the consumers in a free market will judge BEVs according to cost and performance, before environmental concerns. The early adopters of BEVs, however, who generally have high levels of income and/or environmental awareness, are crucial elements to push the BEVs down the learning curve and in spreading positive feedback amongst more resistant consumers (i.e., early majority and late majority) (Egbue and Long, 2012). Here, diffusion subsidies offered by the government are helpful in increasing the attractiveness of BEVs by lowering their price premium (Matteson and Williams, 2015). The success of BEVs, however, is a socio-technical challenge, where both drivers' attitudes and the performance of BEVs must be considered simultaneously (Steinhilber et al., 2013; Tran et al., 2012). The price of the battery pack is the main subject in most existing reports on the price competitiveness of BEVs (Nykvist and Nilsson, 2015; Gerssen-Gondelach and Faaij, 2012; Catenacci et al., 2013). This is partly due to the common belief that a LIB pack is the de facto cost-determining component of BEVs. In such analyses, two types of 
shortcomings are common. First, the price premium of BEVs is cursorily linked to the high price of batteries, and, second, the technical competitiveness of BEVs and their acceptance by consumers are overlooked. A careful price breakup and a clear definition of the target market for BEVs are essential to assess the importance of the first and second points, respectively. Here, we present such an assessment, using available data for the cost/performance of BEVs. We differentiate between the price of a battery pack and the cost associated with the ensemble of electrification components (e.g., battery pack, electric motor, power electronics) in a BEV, namely, the electrification cost. Further, we introduce a technical index that couples the driving range and max-speed of a BEV into a single simple metric, i.e., Mobility-Diffusion coefficient (MDC). This coefficient enables us to more accurately juxtapose BEVs with ICVs from a technical and price point of view. In the first section, we describe our research methodology. In the following sections, we present the results, discussions, and conclusions. The main results are presented and discussed in the following order. First, we estimate the current share of the costs of a battery pack and electrification in the total price of a mid-size BEV. Second, we determine the up-to-date learning rates for the electrification cost and total price of BEVs. Third, we present a breakeven price (initial investment) analysis, compared with ICVs up to 2040, for two technically distinct categories of BEVs: the mainstream of BEVs in the 2016 market and a hypothetical group with a MDC equal in value to that of the current generation of ICVs. Our findings highlight the shortcomings of the current generation of BEVs and help policymakers optimize their support for the BEV industry and related research. 


\section{Methods}

Here, by BEVs and ICVs we refer to passenger cars that are entirely powered by a Lithium-ion battery pack and gasoline, respectively. We build a sample composed of BEV/ICV pairs. In each pair, technical performance (i.e., speed, torque, number of seats) is closely shared between the BEV and ICV, and both vehicles are selected from the same car manufacturer (Table 1). This selection criterion limits the size of our sample to 13 pairs and excludes a series of available BEVs, of which Tesla models are the most notable. The prices for each pair $\left(\right.$ Price $_{\mathrm{ICV}}(\mathrm{i})$, Price $\left._{\mathrm{BEV}}(\mathrm{i})\right)$ correspond to a country in which both vehicles are sold. For our sample, this criterion is met for 9 and 4 pairs by UK and US markets, respectively. The sample, however, is a good representative of the BEV market and covers more than 59\% (Zach, 2016a) and 33\% (Zach, 2016b) of the BEV sales in Europe and the US, respectively, in 2016. BEVs from Tesla are very close to ICVs from a technical standpoint (e.g., driving range and speed) and represent more than $13 \%$ and 30\% of 2016 sales in Europe and the US, respectively. Hence, we further grow the technical space of our BEV sample by including 3 Tesla models (Table B1) to properly set the technical boundaries for the analyses, even though we do not make use of the price of these three models. Appendix $C$ summarizes the main methods and underlying assumptions followed in this paper and will be detailed in the following four subsections. 


\subsection{BEVs' price breakdown}

Following the approach of Weiss et al., (2012) we assume that the ancillary costs (i.e., vehicle chassis, suspension, interior, and mark-up of the retailers) of a BEV (Cost $\left.\operatorname{BEV}_{\mathrm{BEV}}^{\mathrm{anc}}(\mathrm{i})\right)$ are the same as those of its ICV equivalent (Eq. 1)

$\operatorname{Cost}_{\mathrm{BEV}}^{\mathrm{anc}}(i)=f_{\mathrm{ICV}}^{\mathrm{anc}}(i) \cdot \operatorname{Price}_{\mathrm{ICV}}(i)$,

where $f_{\text {ICV }}^{\text {anc }}$ represents the fraction of ancillary costs in the retail price of the ICV. Following Lipman and Delucchi (2003), we assume that $f_{\mathrm{ICV}}^{\mathrm{anc}}=82 \%$ in the rest of study, unless stated otherwise. We define the electrification cost of a BEV $\left(\operatorname{Cost}_{\mathrm{BEV}}^{\text {ele }}(\mathrm{i})\right)$ to cover the price of the LIB pack, the electric motor, power electronics, and other auxiliary components of the electric powertrain. We readily estimate the electrification cost, according to Eq. 2

$\operatorname{Cost}_{\mathrm{BEV}}^{\mathrm{ele}}(i)=$ Price $_{\mathrm{BEV}}(i)-\operatorname{Cost}_{\mathrm{BEV}}^{\mathrm{anc}}(i)$.

It is noteworthy that, for the current niche market of BEVs, the expense of research and development $(R \& D)$ might also represent a significant share of the electrification cost (Delucchi and Lipman, 2001). BEVs without a battery pack are sold as an option by three BEV producers out of 13 in our sample (Smart, Renault, and Nissan). Accordingly, we assume that the price differential between the pack-included and pack-excluded options represents the initial investment for the battery packs $\left(\operatorname{Cost}_{\mathrm{LIB}}(i)\right)$ to be paid by BEV drivers. We treat the price of $\mathrm{BEV} / \mathrm{ICV}$ pairs (Table 1 ) according to the abovementioned 
procedure and estimate the share of electrification, battery pack, and ancillary costs in the total price of BEVs in our sample.

\subsection{Sizing of LIB-pack}

We define the algebraic product of driving range $(r)$ and max-speed $(v)$ as a MobilityDiffusion-Coefficient (MDC). BEVs characterized by high MDC benefit from high speed, high range of drive, or both. We believe that application of such collective indexes is essential to unambiguously asses the competitiveness of BEVs. This is partly due to the dynamics of battery packs in which the practical available energy $\left(E_{\mathrm{p}}\right)$ is a complex function of driving condition (e.g., current/power, temperature) and state-of-health of the pack. Ep is equal to the nominal capacity $\left(E_{\mathrm{n}}\right)$ only at low power drains and the beginning of pack life. $E_{\mathrm{p}}$ deviates from $E_{\mathrm{n}}$ as the power drain (e.g., speed and acceleration) and age of the pack increase. The latter type of deviation is irreversible, and the pack needs to be finally replaced when $E_{\mathrm{p}}$ falls approximately below $80 \%$ of $E_{\mathrm{n}}$ (Safari et al., 2009; Delacourt and Safari, 2016). Hence, we expect that the size of the battery pack (i.e., $\left.E_{\mathrm{n}}\right)$ is a function of the $M D C$ coefficient, i.e., $E_{\mathrm{n}}=f(M D C)$. We process the relevant data (i.e., max-speed, driving range, and battery pack size) of BEVs to find a simple candidate for $f(M D C)$. We use this function to set up a contour map of performance in which the iso-capacity lines (i.e., $E_{\mathrm{n}}=$ const.) help us to approximately size a battery pack for a desired combination of driving range $(r)$ and max-speed $(v)$. In this map, we specify two rectangular zones with diagonal coordinates of $\{(\min (v), \min (r)),(\max (v), \max (r))\}_{\mathrm{BEV}}$ and $\{(\min (v), \min (r)),(\max (v), \max (r))\}_{\mathrm{ICV}}$. We assume that these zones defined by the BEV 
and ICV sets represent the technical status of the BEVs of today and target BEVs of the future, respectively. By doing so, we can further study the prospects of a massive diffusion of BEVs over the course of time for two hypothetical groups of customers. The first group might represent BEVs of choice for the environmentalist and tech-savvy drivers who are willing to overlook the limitations of BEVs for other reasons, namely 'early adopters.' The second group typifies ideal BEVs for those customers who do not want to give up on any of the technical attributes of ICVs (e.g. driving range and speed), namely 'late majority.' We estimate the size of a LIB pack required to power a BEV with average characteristics of each of these zones $\left(B E V^{*}\right)$ according to

$E_{n}^{*}=\frac{1}{\Delta v \Delta r} \iint f(M D C) d r d v$

We then calculate the price of $B E V^{*}$ (Price $e_{\mathrm{BEV}}^{*}$ ) in 2016 according to

Price $_{\mathrm{BEV}}^{*}=\left[1+\overline{f_{\text {ele }}}\left(\frac{E_{n}^{*}}{\overline{E_{n}}}-1\right)\right] \overline{\operatorname{price}_{\mathrm{BEV}}}$,

where, $\overline{f_{\text {ele }}}$ and $\overline{E_{n}}$ are the average share of the cost of electrification in the BEV price $\left(\overline{\text { price }_{\mathrm{BEV}}}\right)$ and the average size of a LIB pack, respectively, i.e., characteristics of our BEV sample (Table 1).

\subsection{Price forecasting}

We forecast the price of two $B E V^{*}$ groups together with the ICVs according to the experience-curve approach, where the production cost of a technological innovation at a given time $(t)$ is assumed to be correlated with its cumulative production $(C P(t))$ (Tsuchiya, 1989; Weis et al., 2012) 
$\operatorname{Price}(t)=\operatorname{Price}\left(t^{0}\right)\left(\frac{C P(t)}{C P\left(t^{0}\right)}\right)^{\frac{\log (1-L R)}{\log 2}}$,

where $L R$, learning rate, is the price scale-down for a doubling in the cumulative production, and $t^{0}$ represents a reference point in time. Here, we employ this equation in two types of analysis. First, in an ex-post analysis, we estimate an effective $L R^{*}$ that explains the concurrent price (i.e., total price and electrification cost) and the production evolution of BEVs between 2010 and 2016

$L R^{*}=1-2^{\frac{\log (\operatorname{Price}(2016))-\log (\operatorname{Price}(2010))}{\log (C P(2016))-\log (C P(2010))}}$,

where we use the available estimates from the literature for global stock (Table D1) of BEVs in $2010(C P(2010))$ and $2016(C P(2016))$, together with the estimates for total price $\left(\right.$ Pric $\left._{\mathrm{BEV}}\right)$ and electrification cost (Cost BEV $_{\mathrm{BE}}^{\mathrm{ele}}$ of BEVs in 2010 (Table E1). We substitute the characteristic prices of our BEV sample $\left(\left(\overline{\operatorname{Cost}_{\mathrm{BEV}}^{\mathrm{ele}}}\right)\right.$ and $\left.\overline{\text { price }_{\mathrm{BEV}}}\right)$ for Price(2016) in Eq.6 to unequivocally solve for learning rates of electrification cost and BEV price. Second, in an ex-ante analysis, we use $L R^{*}$ as an invariant factor, together with the predictions (LimaParis, 2015) for the global increase of BEV stock (Table D1), to forecast the price of BEVs beyond 2016 and up to 2040. We project the price of ICVs up to 2040 in a manner like the way in which we introduced the ex-ante analysis for BEVs. For the ICVs, however, we set $L R$ to $42 \%$ (Weis et al., 2012) and adopt the predictions of the International Energy Agency (IEA) and existing literature (Weis et al., 2012; OECD/IEA, 2016) for the future stock of ICVs (Table D1). 


\subsection{Uncertainty analysis}

In this study, we use a variety of approximations and assumptions to forecast the prices; thus, the resulting uncertainty is considerable. A comprehensive uncertainty analysis is beyond the scope of this paper, and we only examine the sensitivity of price projections to three parameters $(x)$, namely $f_{\mathrm{ICV}}^{\text {anc }}$, learning rates for ICVs $\left(L R_{\mathrm{ICV}}\right)$, and learning rates for BEVs $\left(L R_{\mathrm{BEV}}\right)$. We plot the change of the price ratio $(y)$ between BEVs and ICVs (Price $_{\mathrm{BEv}}$ /Price $\left.\mathrm{ICV}_{\mathrm{CV}}\right)$ for early-adopters and late-majority groups in 2020 and 2035 by changing one parameter at a time, keeping others at the baseline values $\left(x^{0}\right)$ assumed/estimated in this study. In these plots, we measure the slope, i.e., $d y / d x$, around the baseline points $\left(x^{0}\right)$ to approximate the partial derivatives. Here, we define sensitivity $(S)$ as the ratio between the normalized deviations in $y$ and $x$

$S=\frac{d y}{d x} \cdot \frac{x^{0}}{y\left(x^{0}\right)^{\prime}}$

where $S$ multiplied by the error associated with the parameters is simply a measure of error in our price projections.

\section{Results}

The average electrification costs per unit capacity of a LIB pack and per EPA (US Environmental Protection Agency) driving range amount to $690 \pm 40 \$ 2016 / \mathrm{kWh}$ and $120 \pm 10 \$ / \mathrm{km}$, respectively (Figure 1 ). The specific price of a battery pack is sensitive to the pack size (Figure 2). We estimate an average price of $250 \pm 10 \$ 2016 / \mathrm{kWh}$ for a LIB pack ( Cost $\left._{\mathrm{LIB}}\right)$ in 2016. The cost of electrification and a battery pack, on average, contribute to 
$52 \pm 2 \%$ and $19 \pm 1 \%$ of the BEV price, respectively (Figure 3). This finding shows that only $37 \pm 2 \%$ of the electrification cost is attributable to the LIB pack.

The on-road energy consumption of BEVs and ICVs (Table 1) in our sample, under an EPA rating for a combined city-highway profile, is represented by $0.19 \pm 0.00 \mathrm{kWh} / \mathrm{km}$ and $0.66 \pm 0.04 \mathrm{kWh} / \mathrm{km}$, respectively. We notice, however, a lower $M D C$ for BEVs compared to ICVs, with the exception of Tesla vehicles (Figure 4). BEVs in our sample (crosses in Figure 4) have an average $M D C$ of $1.69 \times 10^{4} \pm 0.11 \times 10^{4}\left(\mathrm{~km}^{2} / \mathrm{h}\right)$, which is significantly lower than the average $M D C$ of $9.29 \times 10^{4} \pm 0.61 \times 10^{4}\left(\mathrm{~km}^{2} / \mathrm{h}\right)$ for ICVs (black circle in Figure 4). Tesla vehicles (white circles in Figure 4), however, reach the $M D C$ of ICVs, albeit at a rather high price. We find a decent correlation $\left(\mathrm{R}^{2}=0.99\right)$ between $M D C$ $\left(\mathrm{km}^{2} / \mathrm{h}\right)$ and the capacity $\left(E_{\mathrm{n}}(\mathrm{kWh})\right)$ of the battery pack in BEVs (Figure 4$)$

$E_{\mathrm{n}}=f(M D C)=7 \times 10^{-4} M D C+9.5$.

BEVs (white circles) and ICVs (white squares) from our sample, together with Tesla cars (white diamonds), are scattered on the performance contour map (Figure 5). In this map, Zone $1(125<v<145,85<r<172)$ represents the group of 'early adopters' and is characterized by an average $M D C$ and $E_{\mathrm{n}}$ of $1.73 \times 10^{4} \mathrm{~km} / \mathrm{h}$ and $22 \mathrm{kWh}$ (Eq.3), respectively. The group of 'late majority' is denoted by zone $2(144<v<193,470<r<726)$ and is distinguished by an average $M D C$ and $E_{\mathrm{n}}$ of $10.08 \times 10^{4} \mathrm{~km}^{2} / \mathrm{h}$ and $79 \mathrm{kWh}(\mathrm{Eq} .3)$, respectively. We estimate (Eq.4) that the approximate cost of such BEVs in 2016 is $\$ 28,000 \pm 2,000$ and $\$ 69,000 \pm 1,000$, for the first and second groups, respectively. These 
prices are considerably higher than is the average price of ICVs (Table 1) in our sample (i.e. $\$ 14,000 \pm 1,000)$.

We estimate learning rates of $9 \pm 2 \%$ and $15 \pm 1 \%$ for the price of a BEV and its electrification cost, respectively (Figure 6(a)). Our price projection suggests that a breakeven price, in terms of initial capital cost, is less likely to happen before 2040 (Figure 6(b)) for both groups considered in this study, i.e., early adopters and late majority (Seixas et al., 2015; Tseng et al., 2013; Wu et al., 2015).

The uncertainty analysis shows that the sensitivity of our price projections to the uncertainty of parameters is higher for longer-term forecasts (Figure 7 and Table F1). Aside from $f_{\mathrm{ICV}}^{\text {anc }}$, the other two parameters (i.e., $L R_{\mathrm{BEV}}$ and $L R_{\mathrm{ICV}}$ ) are of equal importance for the reliability of predictions for both the early adopter and the late majority groups. We identify $L R_{\mathrm{BEV}}$ as the most influential parameter in the reliability of our predictions. A $100 \%$ overestimation/ underestimation of this parameter is concurrent with a $76 \%$ error in the price projections. The price forecast for the group of early adopters is almost insensitive to $f_{\mathrm{ICV}}^{\text {anc }}$. For the late majority group, however, a $100 \%$ erroneous assumption for $f_{\mathrm{ICV}}^{\text {anc }}$ results in a $55 \%$ error in price projections.

\section{Discussion}

\subsection{Battery packs: facts and merits}

A gradual decrease of driving range over the life of a LIB pack (up to $25 \%$ after $7.6 \pm 0.4$ years or $139,000 \pm 8,000 \mathrm{~km}$ (Table 1)) is expected due to chemical, electrochemical, and 
mechanical aging (Safari et al., 2009; Delacourt and Safari, 2016) of LIB cells (Appendix A2). Accordingly, we emphasize that the electrification costs of $690 \pm 40 \$_{2016} / \mathrm{kWh}$ and $120 \pm 10 \$ / \mathrm{km}$ determined in this study only refer to BEVs at their beginning of life.

The observed sensitivity of the specific battery price to the size of the LIB pack (Figure 2) might suggest that packs with a higher capacity (e.g., $>25 \mathrm{kWh}$ ) benefit from a lower price given by battery manufacturers. However, this trend, among other factors, might be best interpreted as a difference in pricing strategies amongst BEV producers. Moreover, LIB pack prices reported by the car industry seem to be heavily influenced by marketing strategies and are better referred to as the apparent battery cost. For instance, although Tesla claims a cost for a battery pack that is the lowest $(<190 \$ / \mathrm{kWh})$ among available reports by BEV companies (Figure 2), Tesla BEVs are sold at significantly higher prices, i.e., > 50\$k, compared to others (Langan, 2016; Lambart, 2017). Our estimation for the price of a battery pack $\left(250 \pm 10 \$_{2016} / \mathrm{kWh}\right)$ is in good agreement with the recent report of $300 \$ 2016 / \mathrm{kWh}$ in 2014 (Nykvist and Nilsson, 2015). We notice that the cost of a battery pack does not dominate the electrification cost (Figure 3). An important implication of this result is that the battery price is not an appropriate gauge for the price differential between BEVs and ICVs. Hence, projections presented to the general public for price competitiveness of BEVs that are based solely on the cost of the battery could be misleading. For instance, the price target of $125 \$ / \mathrm{kWh}$ (DOE, 2016) for batteries, set by the US Department of Energy (DOE), is widely reported in the literature (Nykvist and 
Nilsson, 2015; OECD/IEA, 2016) as a threshold below which BEVs become cost competitive with ICVs.

Recent literature on cost simulation of LIBs suggests that the economy of scale is reached at a production threshold of 1 GWh/year (Ciez and Whitacre, 2017; Nelson et al., 2012). A conservative assumption for this threshold, i.e., $10 \mathrm{GWh}$, would correspond to yearly pack productions of 470.000, and 130.000 for the early adopters and late majority groups, respectively. These numbers closely match the statistics of recent global BEV productions (OECD/IEA, 2016) and, hence, further significant price reduction is less likely to be expected from LIB packs by sole economy of scale. This fact, together with the present share of the LIB pack in the electrification costs, i.e., $37 \pm 2 \%$, highlight the significant role of other expenses, e.g., electric power-train, overheads, warranty, and R\&D costs for price competitiveness of BEVs.

Improvements to the engineering and chemical aspects of the battery packs will need to be carried out (Thackeray, 2012; Andre, 2015; Berg, 2015; Wood, 2015). The share of inactive components in the total weight and volume of the cell/module/pack (Appendix A) and the efficiency of cell production (e.g., faster and less energy intensive drying and formation cycles) (Wood et al., 2015) should be minimized and maximized, respectively. Significant improvement to the chemistry/formulation of the electrolyte and electrodes is essential to surpass the current storage limits of LIB packs (Thackeray et al., 2012). In this regard, the challenge for battery research in the coming years is to develop: electrolytes with higher electrochemical/thermal stability (e.g., ionic liquids, gel, 
composite, and solid electrolytes) and full-fledged $\mathrm{Si}$ anode and $\mathrm{Ni}$-/Li-/ Mn-rich layered cathodes (Thackeray et al., 2012; Grey and Tarascon, 2017). A long-term transition towards battery chemistries such as Li-S (Nazar, 2014) and metal-air (Bruce, 2012) seems inevitable, supported by life-cycle-analyses (Ishihara, 2002), to ensure a sustainable future for BEVs.

\subsection{BEV limits $\mathcal{E}$ drivers expectations}

The superior consumption of energy in BEVs (Table 1) is overshadowed by their lower MDC coefficient compared to ICVs (Figure 4). Recent behavioral studies (Frank and Kremas, 2013) show that customers' expectation for driving range in a BEV is far beyond the average driving range $-120 \pm 10 \mathrm{~km}-$ in our BEV sample. Some studies report that drivers in Europe (Bunzeck et al., 2011), the US (Singer, 2016), and worldwide (Bronchard et al., 2011) prefer to have 300, 480, and $430 \mathrm{~km}$ of driving range, respectively. This trend suggests to us that drivers' expectations from a vehicle are heavily geared to the performance of ICVs (Zone 2 in Figure 5), where long driving ranges (e.g. $>500 \mathrm{~km}$ ) and high speed (e.g. $150 \mathrm{~km} / \mathrm{h}$ ) are easily attainable (Egbue and Long, 2012). Accordingly, we believe that the late majority group (zone 2 in Figure 5) approximately reflects the current global expectations from BEVs. However, there is significant disagreement between such expectations and the average daily driving range of $30-50 \mathrm{~km}$ reported for ICV passenger cars (Offer, 2015). 


\subsection{Deceleration in learning process $\mathcal{E}$ vital role of policy support}

Our estimation of $9 \pm 2 \%$ for the $L R$ of BEVs is lower than the $18 \pm 9 \%$ average rate of cost decline in energy demanding technologies, identified earlier by Weiss et al. (2010). A similar $L R$ has been recently reported for electric-two wheelers, the global capacity $(125 \pm 42 \mathrm{GWh})$ of which exceeds that of BEVs $(4 \pm 2 \mathrm{GWh})$ by an approximate factor of 30 (Weiss et al., 2015). A deceleration of the learning process is observed for the total BEV price when the new $L R$ identified in this study is compared with that reported for earlier years, 2007-2012, i.e., 12-15\% (Weis et al., 2012). This trend might reflect the gradual approach of the LIB-based BEVs to a point of maturity, after which the need for process innovations becomes more crucial than are economies of scale. This speculation is supported by the time series of the LIB price, where lower $L R$ values, $6-9 \%$, characterize the recent market (Nykvist and Nilsson, 2015), as compared to higher values, i.e., $17 \%$, reported for earlier years. (Nagelhout and Ros, 2009).

According to our price projections, there is no prospect of breakeven between BEVs and ICVs in the near future. Strong incentives for BEVs and/or disincentives for ICVs (Cowan and Hulten, 1996; Bjerkan et al., 2016) are required to make up for the substantial gap between the purchase price of BEVs and ICVs. Our estimations suggest that incentives of $6 \$ \mathrm{k}$ and 30\$k (Figure 6) are required to realize breakeven in 2025 for early adopters and late majority groups, respectively. 


\subsection{Limitations of the approach $\mathcal{E}$ room for further research}

We recognize three inherent limitations of the approach presented in this research. First, we use an empirical experience-curve method with a constant learning rate that does not account for the dynamics of the price for production factors and the potential heterogeneity of BEVs over the period of analysis (Weis et al., 2010). Second, to size the battery packs, we use an empirical correlation (Eq.8) that only accounts for the driving range and max-speed. In this simplistic approach, the other important design parameters, such as vehicle/battery mass and acceleration, are not explicitly accounted for. Third, we use vehicle prices in the UK and the US as the input data in our experience-curve analysis, and, therefore, care should be taken when applying the results to other countries.

Further research is needed to reinforce and complement the approach presented in this work by studying the following additional details

- The MDC of current generation of BEVs is expected to be a complex function of temperature, driving profile, and age of vehicle. More realistic forecasts are possible upon access to real world data for the dynamics of $M D C$.

- A detailed behavioral study is required to map drivers' expectations from a BEV to define optimal and realistic targets for BEVs. 


\section{Conclusion and Policy Implications}

With the current learning rates for BEVs and their electrification cost, a sole, yet realistic, increase in BEV stock is insufficient to achieve a breakeven price with ICVs for the market in the near future. Higher learning rates are needed, as far as the initial price premium is concerned, to catalyze the transition into electrified road transport. Given the current status of BEV market, i.e., learning rates, cost of LIB packs, and the share of the cost of the LIB pack in the electrification cost, we draw the following conclusions:

1. A shift toward mass production of BEVs with more competitive $M D C$ seems inevitable unless a new mobility/transport culture, tolerant to the current BEV limitations (i.e., driving range and/or speed) is institutionalized among drivers.

2. Collective decisions and policies by governments are necessary to increase the support for BEV buyers (e.g., incentives and tax reduction) and producers. This is essential to partially compensate for the currently significant price difference between a BEV and its ICV counterpart.

3. The DOE target of $100-125 \$ / \mathrm{kWh}$ for the mass penetration of BEVs should be interpreted as a target for the cost of electrification, rather than the cost of LIB packs.

4. The economy of scale currently seems equally important for non-LIB-pack components and, hence, decisive for more rapid achievement of breakeven price with ICVs. 


\section{Acknowledgments}

The author gratefully thanks Dr. P. Azadi and Prof. Jean-Marie Tarascon for fruitful comments and discussions. M. Safari thank the three anonymous reviewers for their valuable and constructive comments. This research was supported by the European Union via the European Regional development fund (EFRO936), Flanders innovation \& Entrepreneurship, and the Province of Limburg. 
Appendix A. State-of-the-art lithium-ion batteries.

A.1. Chemistry and architecture. In current generation of LIBs, the energy storage mechanism relies on the reversible insertion (deinsertion) of lithium into (from) the free crystallographic galleries of the insertion-type active materials (Armand and Tarascon, 2008). Graphite is the dominant choice for the active material in the anode while more options are available for the cathode, i.e., $\mathrm{LiNi}_{x} \mathrm{Mn}_{\mathrm{y}} \mathrm{Co}_{z} \mathrm{O}_{2}(x+y+z=1), \mathrm{LiMn}_{2} \mathrm{O}_{4}, \mathrm{LiFePO}_{4}$, and $\mathrm{LiNi}_{x} \mathrm{Co}_{\mathrm{y}} \mathrm{Al}_{z} \mathrm{O}_{2}(x+y+z=1)$. These materials can host a high concentration of lithium equivalent to gravimetric and volumetric charge densities as high as $370 \mathrm{Ah} / \mathrm{kg}$ and 875 Ah/l, respectively (Table A1). A series of inactive components are conjoined with the active materials to build up a practical energy-storage device and so a drop in the specific energy and energy density then ensued. A homogenous mixture of active material, conductive additive (e.g., carbon black), and binder (e.g., PVDF) is coated (i.e., thickness of 50-100 micron) over thin foils of Aluminum and Copper (i.e., few micron) to form cathode and anode electrodes, respectively. A thin separator (e.g., porous polymeric film) is placed between the two electrodes to form a sandwich layer of which the open porosity is filled with a liquid electrolyte (e.g., $\mathrm{LiPF}_{6}$ dissolved in Ethylene Carbonate). The sandwich layer is sized to the desired capacity and enclosed/sealed inside a cylindrical, prismatic, or pouch cell (Blomgren, 2017). Such LIB cells are characterized by an average discharge potential of $3.3-3.7 \mathrm{~V}$ and currently achieve gravimetric and volumetric energy densities as high as $220 \mathrm{Wh} / \mathrm{kg}$ and $620 \mathrm{Wh} / \mathrm{l}$, respectively (Table A2). In the course of integration of cells into the modules and pack additional inactive components are included into the pack architecture to ensure the long-term optimal and safe performance of the batteries: housing/cover, insulation, connectors/wires/sensors, coolant channels, and the hardware for battery management system (BMS). The contribution of these 
elements to the mass/volume of the cell/module/pack correlates with the size of storage (i.e., cap $(\mathrm{Wh}))$ and is a serious setback to the effective gravimetric (SE (Wh/ $\mathrm{kg}))$ and volumetric $(E D(\mathrm{Wh} / \mathrm{l}))$ energy density of the LIBs (Figure A1).

A.2. Aging $\mathcal{E}$ Safety. Long lifespan (i.e., 10 to 15 years) is a necessary requirement for LIBs that are targeted for BEVs. Unfortunately, the performance of LIBs declines over time as a consequence of variety of aging processes. Interfacial film formation, ionic/electronic isolation of the active-materials, as well as structural degradation and dissolution of active materials into the liquid electrolyte are amongst the most frequently observed degradation phenomena for current generation of LIBs. These degradation phenomena are thermally activated and usually pronounced at fully discharged and charged states (Delacourt and Safari, 2016). Hence, reliable control of temperature and state-of-charge, done by BMS, is essential in LIB packs to avoid premature end-of-life and safety threats (Chaturvedi, 2010). In this regard, it is noteworthy that the liquid solvents (i.e., linear and cyclic alkyl carbonates) in the formulation of LIBs' electrolyte are flammable. The combustion energy of the vented solvent (e.g., following leakage, abuse, or thermal runaway) is several times larger than the electrical energy stored in the battery (Eshetu, 2013).

Table A1 Charge-storage characteristics of the Li-insertion active materials used in the current generation of LIBs for BEVs (Berg, 2015).

\begin{tabular}{c|c|c} 
Insertion material & Specific charge (Ah/kg) & Charge density (Ah/l) \\
\hline $\mathrm{LiNi}_{0.33} \mathrm{Mn}_{0.33} \mathrm{Co}_{0.33} \mathrm{O}_{2}$ & 170 & 807 \\
\hline $\mathrm{LiMn}_{2} \mathrm{O}_{4}$ & 130 & 560 \\
\hline $\mathrm{LiNi}_{0.8} \mathrm{Co}_{0.15} \mathrm{Al}_{0.05} \mathrm{O}_{2}$ & 190 & 875 \\
\hline $\mathrm{LiFePO}_{4}$ & 160 & 585 \\
\hline Graphite & 370 & 815 \\
\hline
\end{tabular}


Table A2 Gravimetric and volumetric energy densities for the current generation of LIB

\section{Cell/module/pack}

SL451223

SL332029

SL293452H

SL355052

SL434658

SL584259

LP053441AR1U

LP053843ARU

LP664450AU

NRC18650

NCR18650PF

UR18650A

\section{7}

18

19

20

21

22

23

24

25

26

Pack-Renault twizzy

57 Pack-Peugot ion

58 Pack-Renault zoe

59 Pack-Ranault kangoo 60 \begin{tabular}{|l|l} 
Storage capacity (Wh) & Specific energy (Wh/kg)
\end{tabular} 0.31

0.52

1.8

3.1

4.5

\begin{tabular}{l|c}
5.5 & 198 \\
\hline 3.1
\end{tabular}

\begin{tabular}{l|r}
5.5 & 198 \\
\hline 3.1 & 197 \\
\hline 3.8 & 173
\end{tabular}

\begin{tabular}{l|r}
3.8 & 173 \\
\hline 5.6 & 181 \\
\hline
\end{tabular}

\begin{tabular}{l|c}
5.6 & 181 \\
\hline 12.6 & 214
\end{tabular}

\begin{tabular}{l|l}
5.6 & 181 \\
\hline 12.6 & 214
\end{tabular}

\begin{tabular}{l|l}
12.6 & 207 \\
\hline 8.1 & 176
\end{tabular}

8.1

11.1

8.5

4.7

4

4.5

2.6

2.6

63

1500

21200

320

81.5

640

3.63

8.25

66

540

504

700

98

23300

15600

18400

27000

24200

18800

17600

85000

23000

24000

16000

28000

6100

14500

22000

22000
Energy density (Wh/l)

253

270

346

391

387

394

394

424

388

577

577

453

620

460

483

474

469

388

437

250

165

70
Source

BYD (2016)

BYD (2016)

BYD (2016)

BYD (2016)

BYD (2016)

BYD (2016)

BYD (2016)

BYD (2016)

BYD (2016)

Panasonic (2016)

Panasonic (2016)

Panasonic (2016)

Panasonic (2016)

Panasonic (2016)

Panasonic (2016)

Panasonic (2016)

Panasonic (2016)

Panasonic (2016)

Panasonic (2016)

Enerdel (2016)

Enerdel (2016)

Enerdel (2016)

Calb (2016)

Calb (2016)

Calb (2016)

Calb (2016)

A123 (2016)

A123 (2016)

A123 (2016)

Ebikes (2016)

Ebikes (2016)

Ebikes (2016)

Ebikes (2016)

Microvast (2016)

Microvast (2016)

Idaho (2016)

Idaho (2016)

Idaho (2016)

Idaho (2016)

Idaho (2016)

Idaho (2016)

Idaho (2016)

Idaho (2016)

Idaho (2016)

Idaho (2016)

Idaho (2016)

Idaho (2016)

Idaho (2016)

Idaho (2016) 
Appendix B. Technical specifications of Tesla BEVs.

Table B1 Technical specifications of three BEV models from Tesla (Tesla, 2016).

\begin{tabular}{cccc}
\hline Model & $\begin{array}{c}\text { LIB pack } \\
\mathbf{( k W h )}\end{array}$ & $\begin{array}{c}\text { Driving range } \\
\mathbf{( k m )}\end{array}$ & $\begin{array}{c}\text { Max speed } \\
\mathbf{( k m / h )}\end{array}$ \\
\hline S 60D & 60 & 350 & 210 \\
S 75D & 75 & 420 & 230 \\
S 90D & 90 & 470 & 250 \\
\hline
\end{tabular}


Appendix C. Flowchart of methods \& summary of main assumptions/approximations

Table C1. Summary of main assumptions/approximations used in this paper.

Figure C3 A summary of methods and procedures followed throughout the paper for: price breakdown, LIB-pack sizing, and price projection of BEVs.

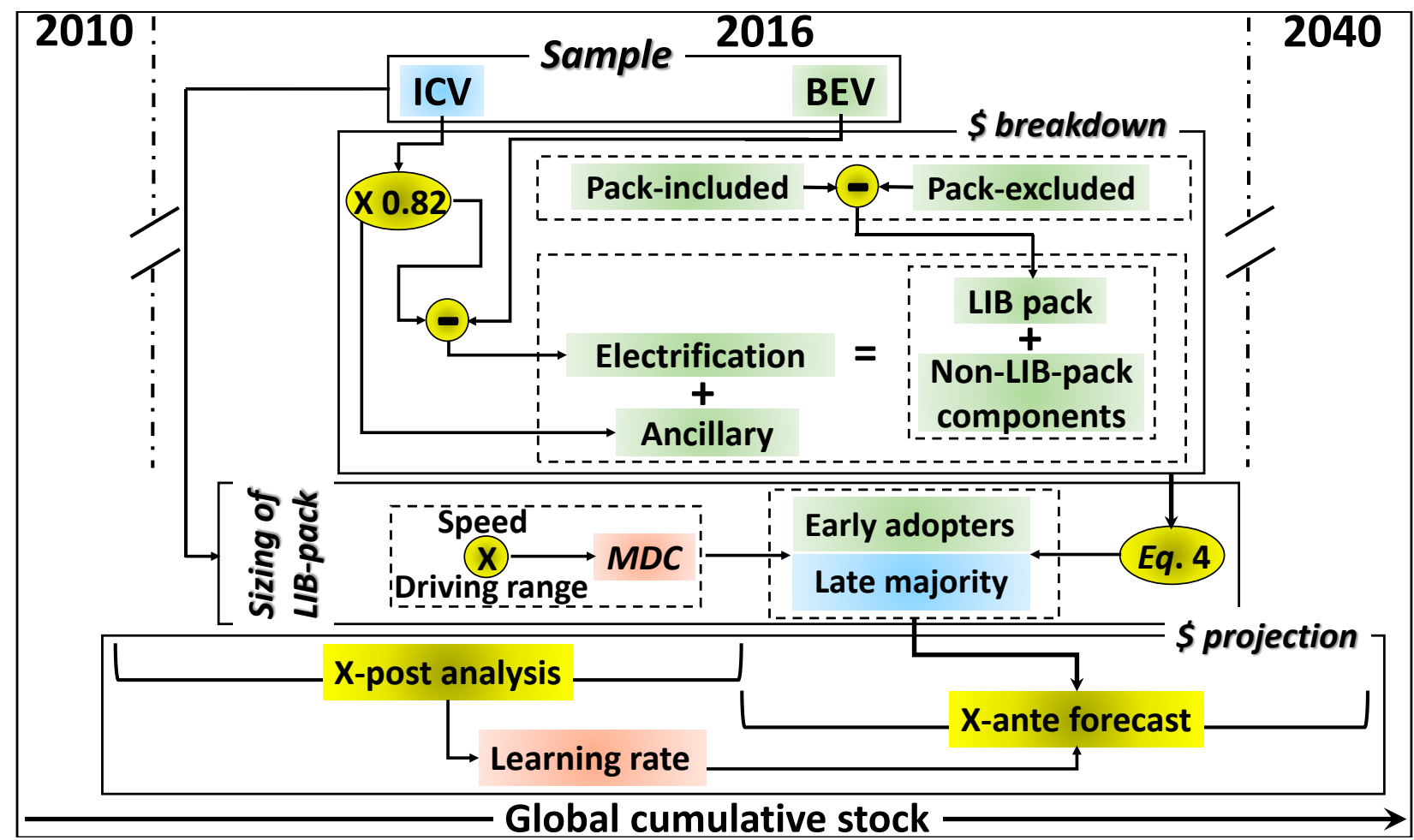

\section{Underlying Assumptions}

General (a) Tax, delivery cost, and governmental incentives are not included in the price analyses.

(b) Breakeven price analyses for BEVs and ICVs only account for the initial investment and not the total cost of ownership.

(c) The variance in the chemical formulation (Table A1) and pack architecture of BEVs (Table 1) is neglected in the price analyses.

Eq. 1 (a) The fraction of ancillary cost in the price of ICVs $\left(f_{\text {ICV }}^{\text {anc }}\right)$ is independent of vehicle brand.

(b) The ancillary cost of a BEV is equal to that of an ICV with similar specifications.

$\begin{array}{ll}\text { Eq. } 2 & \text { (a) The price of BEV is made up by two distinct costs: electrification \& ancillary. }\end{array}$

Eq. 3 The mean size of LIB packs corresponding to the ensemble of points, (speed, range), enclosed by a rectangle (area of $\Delta v . \Delta r$ ) in Figure 5 is determined by a surface integral.

Eq. $4 \quad$ (a) The ancillary cost of a mid-size BEV is set to be that of the average for BEV sample and independent of the electrification cost (i.e., size of the LIB-pack).

(b) The electrification cost in a BEV is linearly proportional to the size of LIB-pack.

Eqns. 5, 6. Learning rate is independent of time/stock. 
Appendix D. Global cumulative stock of BEVs and ICVs.

Table D1 Cumulative stock of ICV and BEV passenger cars until 2040.

\begin{tabular}{|c|c|c|}
\hline \multirow[t]{2}{*}{ Year } & \multicolumn{2}{|c|}{ Cumulative stock in million units } \\
\hline & $\mathrm{ICV}^{\mathrm{a}}$ & $\mathrm{BEV}^{\mathrm{b}}$ \\
\hline 2010 & 2338 & $0.01^{\mathrm{b}}$ \\
\hline 2011 & 2400 & $0.01^{\mathrm{b}}$ \\
\hline 2012 & 2465 & $0.05^{\mathrm{b}}$ \\
\hline 2013 & 2532 & $0.11^{\mathrm{b}}$ \\
\hline 2014 & 2603 & $0.22^{\mathrm{b}}$ \\
\hline 2015 & 2677 & $0.41^{\mathrm{b}}$ \\
\hline 2016 & 2752 & $0.74^{\mathrm{b}}$ \\
\hline 2017 & 2829 & $3.7^{\mathrm{c}}$ \\
\hline 2018 & 2907 & $6.2^{c}$ \\
\hline 2019 & 2987 & $9.1^{\mathrm{c}}$ \\
\hline 2020 & 3068 & $12.7 \mathrm{c}$ \\
\hline 2021 & 3150 & $17 \mathrm{c}$ \\
\hline 2022 & 3234 & $22.3^{c}$ \\
\hline 2023 & 3319 & $28.8^{\mathrm{c}}$ \\
\hline 2024 & 3406 & $36.5^{c}$ \\
\hline 2025 & 3494 & $45.8^{c}$ \\
\hline 2026 & 3585 & $56.7^{c}$ \\
\hline 2027 & 3679 & $69.4^{\mathrm{c}}$ \\
\hline 2028 & 3776 & $84.1^{\mathrm{c}}$ \\
\hline 2029 & 3876 & $101^{c}$ \\
\hline 2030 & 3979 & $120.2^{c}$ \\
\hline 2031 & 4084 & $142^{\mathrm{c}}$ \\
\hline 2032 & 4190 & $166.4^{\mathrm{c}}$ \\
\hline 2033 & 4299 & $193.7^{c}$ \\
\hline 2034 & 4409 & $224^{c}$ \\
\hline 2035 & 4521 & $257.6^{c}$ \\
\hline 2036 & 4638 & $294.5^{c}$ \\
\hline 2037 & 4757 & $334.9^{c}$ \\
\hline 2038 & 4879 & $379.1^{c}$ \\
\hline 2039 & 5003 & $427.2^{c}$ \\
\hline 2040 & 5131 & $479.3^{c}$ \\
\hline
\end{tabular}

a Estimated based on (OECD/IEA, 2016; Weis et al., 2012).

b Estimated based on (OECD/IEA, 2016).

c Assumed based on (LimaParis, 2015). 
Appendix E. Estimation of BEV price and electrification cost in 2010.

We estimate the BEV price and electrification cost for 3 mass-produced BEVs in 2010 based on data (Table E1) provided by Weiss et al., (2012). Accordingly, in our experiencecurve analyses, the market status in 2010 is represented by BEV price and electrification cost of $2,330 \pm 300 \$ 2016 / \mathrm{kWh}$ and $1,870 \pm 20 \$ 2016 / \mathrm{kWh}$, respectively.

Table E1. Price data for 3 mass-produced BEVs in 2010.

\begin{tabular}{cccc}
\hline BEV Model & $\begin{array}{c}\text { LIB pack } \\
\mathbf{( k W h )}\end{array}$ & $\begin{array}{c}\text { Specific price } \\
\mathbf{( \$ 2 0 1 6} / \mathbf{k W h})\end{array}$ & $\begin{array}{c}\text { Electrification } \\
\text { cost } \mathbf{( \$ 2 0 1 6} / \mathbf{k W h})\end{array}$ \\
\hline Nissan Leaf & 24 & $1720^{a}$ & $1840^{a}$ \\
i-Miev & 16 & $2650^{a}$ & $1900^{a}$ \\
C-Zero & 16 & $2610^{a}$ & $1880^{a}$ \\
\hline \multicolumn{4}{r}{ a Own estimate based on analysis of Weis et al., (2012). }
\end{tabular}

\begin{abstract}
Appendix F. Sensitivity of price projections to $f_{I C V}^{a n c}, L R_{\mathrm{BEV}}$, and $L R_{\mathrm{ICV}}$, according to Eq.7 and Figure 7.

Table F1. Prediction sensitivity $(S)$ of Price $_{\mathrm{BEV}} /$ Price $_{\mathrm{ICV}}$ to $f_{I C V}^{a n c}, L R_{\mathrm{BEV}}$, and $L R_{\mathrm{ICV}}$ for the early adopters and late majority groups in 2020 and 2035.
\end{abstract}

\begin{tabular}{|c|c|c|c|c|}
\hline \multirow[b]{3}{*}{ year } & \multicolumn{4}{|c|}{ Sensitivity $(S)$} \\
\hline & \multicolumn{2}{|c|}{ Early adopters } & \multicolumn{2}{|c|}{ Late majority } \\
\hline & 2020 & 2035 & 2020 & 2035 \\
\hline$f_{\mathrm{ICV}}^{\text {anc }}$ & 0.01 & 0.01 & 0.55 & 0.55 \\
\hline$L R_{\mathrm{BEV}}$ & 0.35 & 0.74 & 0.33 & 0.76 \\
\hline$L R_{\mathrm{ICV}}$ & 0.11 & 0.53 & 0.11 & 0.54 \\
\hline
\end{tabular}




\section{References}

1. Armand M, Tarascon J-M. Building better batteries. Nature 2008; 451: 652-657.

2. Andre D, Kim S-J, Lamp P, Lux S. F, Maglia F, Paschos O, Sitaszny B. Future generations of cathode materials: an automotive industry perspective. J. Mater. Chem. A 2015; 3: 6709-6732.

3. A123, 2016. Lithium-battery products. Source: < http:// www.a123systems.com/lithium-battery.htm> (accessed 10.12.16).

4. Berg E. J, Villevieille C, Streich D, Trabesinger S, Novak P. Rechargeable batteries: grasping for the limits of chemistry. J. Electrochem. Soc. 2015; 162: A2468-A2475.

5. Bruce P. G, Freunberger S. A, Hardwick L. J, Tarascon J-M. Li-O 2 and Li-S Batteries with High Energy Storage. Nature Materials 2012; 11: 19-29.

6. Bunzeck I, Feenstra C. F. J., Paukovic M. 2011. Preferences of potential users of electric cars related to charging - a survey in eight EU countries. Source: <http://www.d-incert.nl/wp-content/uploads/2011/05/rapportage_ECN.pdf> (accessed 16.05.17).

7. Bronchard S, McGuinness S, Narich C, Noom M, Raut C, Schutz M, Stark M, Ubbink P, Viglino M, Vos A., 2011. Plug-in electric vehicles: changing perceptions, Heading bets. Source: < https://www.accenture.com/us-en/new-applied-now > (accessed 16.05.17).

8. Blomgren G.E. The development and future of lithium-ion batteries. J. Electrochem. Soc. 2017; 164: A5019-A5025.

9. BYD, 2016. Products. Source: < http://www.bydit.com/doce/products/LiEnergyProducts/> (accessed 10.12.16).

10. Cowan R, Hulten S. Escaping lock-in: the case of the electric vehicle. Technological Forecasting and Social Change 1996; 53: 61-79.

11. Ciez R. E, Whitacre J. F. Comparison between cylindrical and prismatic lithiumion cell costs using a process based cost model. J. Power Sources 2017; 340: 273281.

12. Catenacci M, Verdolini E, Bosetti V, Fiorese G. Going electric: Expert Survey on the Future of Battery Technologies for Electric Vehicles. Energy Policy 2013; 61: 403-413.

13. Citroen, 2016. C-Zero. Source: < http:/ / www.citroen.co.uk/new-cars-andvans/citroen-range/citroen-c-zero> (accessed 1.11.16).

14. Chevrolet, 2016. Spark - Specs. Source: < http:/ / www.chevrolet.com/spark-evelectric-vehicle.html> (accessed 1.11.16).

15. Choi J.W, Aurbach D. Promise and reality of post-lithium-ion batteries with high energy densities. Nature Reviews Materials 2016; 16013.

16. Calb, 2016. Products. Source: < http://en.calb.cn/> (accessed 10.12.16).

17. Chaturvedi N, Klein R, Christensen J, Ahmed J, Kojik A. Algorithms for advanced battery-management systems. IEEE Control Systems 2010; 30: 49-68. 
18. Dunn B, Kamath H, Tarascon J-M. Electrical Energy Storage for the Grid: A Battery of Choice. Science 2011; 334: 928-935.

19. Delacourt C, Safari M., 2016. Mathematical modeling of aging of Li-ion batteries, in: Franco A.A, Doublet M.L, Besler W., Physical Multiscale Modeling and Numerical Simulation of Electrochemical Devices for Energy Conversion and Storage. Springer London, pp. 151-190.

20. Delucchi M. A, Lipman T. E. An analysis of the retail and lifecycle cost of batterypowered electric vehicles. Transportation Research Part D 2001; 6: 371-404.

21. DOE, 2016. Vehicle technologies office: batteries. Source: <https://energy.gov/eere/vehicles/vehicle-technologies-office-batteries> (accessed 16.05.17).

22. Egbue O, Long S. Barriers to widespread adoption of electric vehicles: an analysis of consumer attitudes and perceptions. Energy Policy 2012; 48: 717-729.

23. Eshetu G, Grugeon S, Laruelle S, Boyanov S, Lecocq A, Bertrand J-P, Marlair G. In-depth safety-focused analysis of solvents used in electrolytes for large scale lithium ion batteries. Phys.Chem.Chem.Phys. 2013; 15: 9145-9155.

24. Ebikes, 2016. Batteries. Source: < http:// www.ebikes.ca/shop/electric-bicycleparts/ batteries.html $>$ (accessed 10.12.16).

25. Enerdel, 2016. Products. Source: < http:// enerdel.com/> (accessed 10.12.16).

26. Flink J.J. America adopts the automobile: 1895-1910. Cambridge University Press, Cambridge, MA, 1970.

27. Franke T, Krems J. F. What drives range preferences in electric vehicle users. Transport Policy 2013; 30: 56-62.

28. Ford, 2016. Models and Specs. Source: $<$ http://www.ford.com/cars/focus/trim/electric/> (accessed 1.11.16).

29. Fiat, 2016. 500e - Specs. Source: <http://www.fiatusa.com/en/500e/> (accessed 1.11.16).

30. Goodenough J. B, Park K-S. The Li-Ion Rechargeable Battery: A perspective. J. Am. Chem. Soc. 2013; 135: 1167-1176.

31. Gerssen-Gondelach S. J, Faaij A. P. C. Performance of Batteries for Vehicles on Short and Longer Term. J. Power Sources 2012; 212: 111-129.

32. Grey C.P, Tarascon J-M. Sustainability and in situ monitoring in battery development. Nature Materials 2017; 16:45-56.

33. Ishihara K, Kihira N, Tereda N, Iwahori T, Nishimura K. Life cycle analysis of large-size lithium-ion secondary batteries developed in the Japanese national project. Proceeding from $5^{\text {th }}$ Ecobalance Conference 2002. 293-294.

34. Idaho, 2016. Advanced vehicle testing activity-Idaho national laboratory. Source: < https:/ /avt.inl.gov/fuel-type/ electric> (accessed 10.12.16).

35. Kia, 2016. Models and Specs. Source: <http://www.kia.com/uk/new-cars/soulev/specification/> (accessed 1.11.16).

36. Langan C. 2016. UBS sees Tesla's (TSLA) model 3 as unprofitable. Source: < https://www.streetinsider.com/Analyst+Comments/UBS+Sees+Telsas+\%28TSL A\%29+Model+3+As+Unprofitable/11540932.html> (accessed 16.05.17). 
37. Lambert F. 2017. Tesla is now claiming 35\% battery cost reduction at Gigafactory https:/ / electrek.co/2017/02/18/tesla-battery-cost-gigafactory-model-3/> (accessed 16.05.17).

38. LimaParis, 2015. Paris declaration on the electro-mobility. Source: <http:/ / newsroom.unfccc.int/media/521376/paris-electro-mobilitydeclaration.pdf $>$ (accessed 1.11.16).

39. Lipman T. E, Delucchi M. A. 2003. Hybrid-electric vehicle design - retail and life cycle cost analysis. Energy Foundation. Source: < http:/ / citeseerx.ist.psu.edu/viewdoc/download?doi=10.1.1.196.5234\&rep=rep1 \&type $=$ pdf $>$ (accessed 1.11.16).

40. Ma H, Balthasar F, Tait N, Riera-Palou X, Harrison A. A new comparison between the life cycle greenhouse gas emissions of battery electric vehicles and internal combustion vehicles. Energy Policy 2012; 44: 160-173.

41. Matteson S, Williams E. Learning dependent subsidies for lithium-ion electric vehicle batteries. Technological Forcasting and Social Change 2015; 92: 322-331.

42. Mitsubishi, 2016. I-MiEV. Source: <http:/ / www.mitsubishicars.com/imiev\#vehicle-stats> (accessed 1.11.16).

43. Microvast, 2016. Products. Source: < http://www.microvast.com/index.php/solution/solution_cell> (accessed 10.12.16).

44. Nagelhout D, Ros J. P. M., 2009. Electrisch autorijden - Evaluatie van transities op basis van systemopties. Planbureau voor de leefomgeving. Source: <http:/ / www.rivm.nl/bibliotheek/rapporten/500083010.pdf> (accessed 1.11.16).

45. Nelson P, Gallagher K, Bloom I., 2012. Modeling the performance and cost of lithium-ion batteries for electric-drive vehicles. Argonne National Laboratory. Source: <http://www.ipd.anl.gov/anlpubs/2011/10/71302.pdf> (accessed 1.11.16).

46. Nykvist B, Nilsson M. Rapidly falling costs of battery packs for electric vehicles. Nature Climate Change 2015; 5: 329-332.

47. Nazar L. F, Cuisinier M, Pang Q. Lithium-Sulfur Batteries. MRS Bulletin 2014; 39.

48. Nissan, 2016. Leaf - Source: <https://www.nissan.co.uk/vehicles/newvehicles/leaf.html> (accessed 1.11.16).

49. Offer G. J. Automated vehicles and electrification of transport. Energy Environ. Sci. 2015; 8: 26-30.

50. OECD/IEA, 2016. Global EV outlook 2016 - OECD/IEA report. Source: <https://www.iea.org/publications/freepublications/publication/Global_EV_ Outlook_2016.pdf $>$ (accessed 1.11.16).

51. Peugeot, 2016. Ion. Source: < http://www.peugeot.co.uk/showroom/ion/5door $/>$ (accessed 1.11.16).

52. Panasonic, 2016. Lithium ion batteries. Source: < https:/ / eu.industrial.panasonic.com/products/batteries-energy- 
products/secondary-batteries-rechargeable-batteries/lithium-ion-batteries> (accessed 10.12.16).

53. Rogers E. M. Diffusion of Innovations. Third edition, Collier Macmillan Publishers, 1983 London.

54. REN21, 2015. Renewables 2015 Global status report. Source: <http:/ / www.ren21.net/wp-content/uploads/2015/07/REN12GSR2015_Onlinebook_low1.pdf> (accessed 1.11.16).

55. Renault, 2016. Models and Prices. Source: <https://www.renault.co.uk/vehicles/new-vehicles/zoe.html> (accessed 1.11.16).

56. Ramachandran S, Stimming U. Well to wheel analysis of low carbon alternatives for road traffic. Energy Environ. Sci. 2015; 8: 3313-3324.

57. Steinhilber $S$, Wells P, Thankappan S. Socio-technical inertia: understanding the barriers to electric vehicles. Energy Policy 2013; 60: 531-539.

58. Singer M., 2016. Consumer views on plug-in electric vehicles - National BenchmarkReport.NREL.Source:<http:/ / www.afdc.energy.gov/uploads/public ation/consumer_views_pev_benchmark.pdf> (accessed 16.05.17).

59. Smart, 2016. Smart fortwo. Source: <https://www.smart.com/be/nl/index/smart-fortwo-electric-drive.html> (accessed 1.11.16).

60. Seixas J, Simoes S, Dias L, Kanudia A, Fortes P, Gargiulo M. Assessing the costeffectiveness of electric vehicles in European countries using integrated modeling. Energy Policy 2015; 80: 165-176.

61. Safari M, Morcrette M, Teyssot A, Delacourt C. Multimodal physics-based aging model for life prediction of Li-ion batteries. Journal of Electrochem. Soc. 2009; 156(3): A145-A153.

62. Tsuchiya H. Photovoltaics cost analysis based on the learning curve. Clean and safe energy forever. Congress of International Solar Energy, Kobe, Japan 1989.

63. Tseng H-K, S.Wu Jy, Liu X. Affordability of electric vehicles for a sustainable transport system: An economic and environmental analysis. Energy Policy 2013; 61: 441-447.

64. Tesla, 2016. Tesla model S. Source: < https://www.tesla.com/models> (accessed 1.6.2017).

65. Thackeray M. M, Wolverton C, Isaacs E. D. Electrical energy storage for transportation - approaching the limits of, and going beyond, lithium-ion batteries. Energy Environ. Sci. 2012; 5: 7854-7863.

66. Tran M, Banister D, Bishop J. D. K, McCulloch M. D. Realizing the electric-vehicle revolution. Nature Climate Change 2012; 2: 328-333.

67. VW, 2016a. eGolf - Models - Specifications. Source: <http://www.volkswagen.co.uk/new/golf-vii-pa/which-model-compare> (accessed 1.11.16).

68. VW, 2016b. eUp - Models - Specifications. Source: <http:/ / www.volkswagen.co.uk/new/e-up-nf/which-modelcompare/details/1651\#!\#overview> (accessed 1.11.16). 
69. Whittingham M. S. Electrical Energy Storage and Intercalation chemistry. Science 1976; 192: 1126-1127.

70. Weiss M, Patel M. K, Junginger M, Perujo A, Bonnel P, Van Grootveld G. On the electrification of road transport - learning rates and price forecasts for hybridelectric and battery -electric vehicles. Energy Policy 2012; 48: 374-393.

71. Wood D. L, Li J, Daniel C. Prospects for reducing the processing cost of lithium ion batteries. J. Power Sources 2015; 275: 234-242.

72. Weiss M, Junginger M, K. Patel M, Blok K. A review of experience curve analyses for energy demand technologies. Technological Forcasting \& Social changes 2010; 77: 411-428.

73. Weiss M, Dekker P, Moro A, Scholz H, K. Patel M. On the electrification of road transportation - A review of the environmental, economic, and social performance of electric two-wheelers. Transportation Research Part D 2015; 41: 348366.

74. Wu G, Inderbitzin A, Bening C. Total cost of electric vehicles compared to conventional vehicles: A probabilistic analysis and projection across market segments. Energy Policy 2015; 80: 196-214.

75. Y. Bjerkan K, E. Norbech T, E. Nordtomme M. Incentives for promoting battery electric vehicle (BEV) adoption in Norway. Transportation Research Part D 2016; 43: 169-180.

76. Zach, 2016a. Top-selling fully electric cars. Source: < https:/ / evobsession.com/15-europe-electric-car-charts/> (accessed 1.6.2017).

77. Zach, 2016b. US \& Europe and China electric car sales in 2016. Source:https:/ / evobsession.com/us-europe-china-electric-car-sales-2016/ (accessed 1.6.2017). 
Table 1. Prices and technical specifications of 13 mid-size (2-5 seats) battery electric vehicles available in 2016, together with those of the equivalent ICV pairs. Tax, delivery cost, and governmental incentives are excluded. * One or two additional ICV models, upon availability, with more options are included in the calculations to compensate for the high-tech (e.g., navigation system, speed-sensitive volume control) features in BEVs.

\section{BEV}

1 Samart ${ }^{\mathrm{C}}$

15 mart fortwo

16eugot ion

17 eugot $108 \mathrm{Vti}^{\mathrm{c}}$

19 -zero

$261 \mathrm{Vti}$

2i1MiEV ${ }^{b}$

\begin{tabular}{c|c|c|}
$\begin{array}{c}\text { LIB } \\
\text { pack } \\
(\mathbf{k W h})\end{array}$ & $\begin{array}{c}\text { EPA } \\
\text { range } \\
(\mathbf{k m})\end{array}$ & \\
\hline $\begin{array}{c}\text { Tank } \\
\text { capacity } \\
\text { (liter) }\end{array}$ & & \\
\end{tabular}

\begin{tabular}{c|c}
$\begin{array}{c}\text { Max } \\
\text { speed } \\
(\mathrm{km} / \mathrm{hr})\end{array}$ \\
\hline $\begin{array}{c}\text { Max } \\
\text { speed } \\
(\mathrm{km} / \mathrm{hr})\end{array}$ \\
\hline
\end{tabular}

\begin{tabular}{|c|c|c|}
$\begin{array}{c}\text { Peak } \\
\text { power } \\
(\mathrm{kW})\end{array}$ & $\begin{array}{c}\text { Peak } \\
\text { torque } \\
(\mathrm{N} . \mathrm{m})\end{array}$ & $\begin{array}{c}\text { BEV } \\
\text { price } \\
(\mathbf{\$})\end{array}$ \\
\hline $\begin{array}{c}\text { Peak } \\
\text { power } \\
(\mathrm{kW})\end{array}$ & $\begin{array}{c}\text { Peak } \\
\text { torque } \\
(\mathrm{N} . \mathrm{m})\end{array}$ & $\begin{array}{c}\text { ICV } \\
\text { price* } \\
(\$)^{\mathrm{a}}\end{array}$ \\
\hline
\end{tabular}

Pack

price efficiency

(\$) $(\mathrm{kWh} / \mathrm{km})$

\begin{tabular}{|c|c|}
\multicolumn{2}{|c|}{$\begin{array}{c}\text { LIB pack } \\
\text { warranty }\end{array}$} \\
\hline years & $\mathrm{km}$ \\
\hline
\end{tabular}

\begin{tabular}{l|l|l}
17.6 & 110 & 130
\end{tabular}

\begin{tabular}{l|l}
55 & 130
\end{tabular}

2Rlirage 1.2 ${ }^{\mathrm{b}}$

\begin{tabular}{c|c|c}
35 & & \\
\hline 14.5 & 90 &
\end{tabular}

$130 \quad 55$

25

24 park

28 issan Visiac

2IXote $1.2^{c}$

218issan Acenta

29ote $1.2^{c}$

3 Golf

$32^{3}$ rendline 1.2c

3ब्ड Up

37ake Up 1

35 at $500 \mathrm{e}^{b}$

3500 Pop $^{b}$

37 senault Zoe

39lio Expression ${ }^{c}$

4 Wia Soul

4 4loul start ${ }^{\mathrm{c}}$

42ord Focus ${ }^{b}$

${ }_{44}^{43}$ Hatch $^{\mathrm{b}}$ 


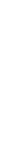
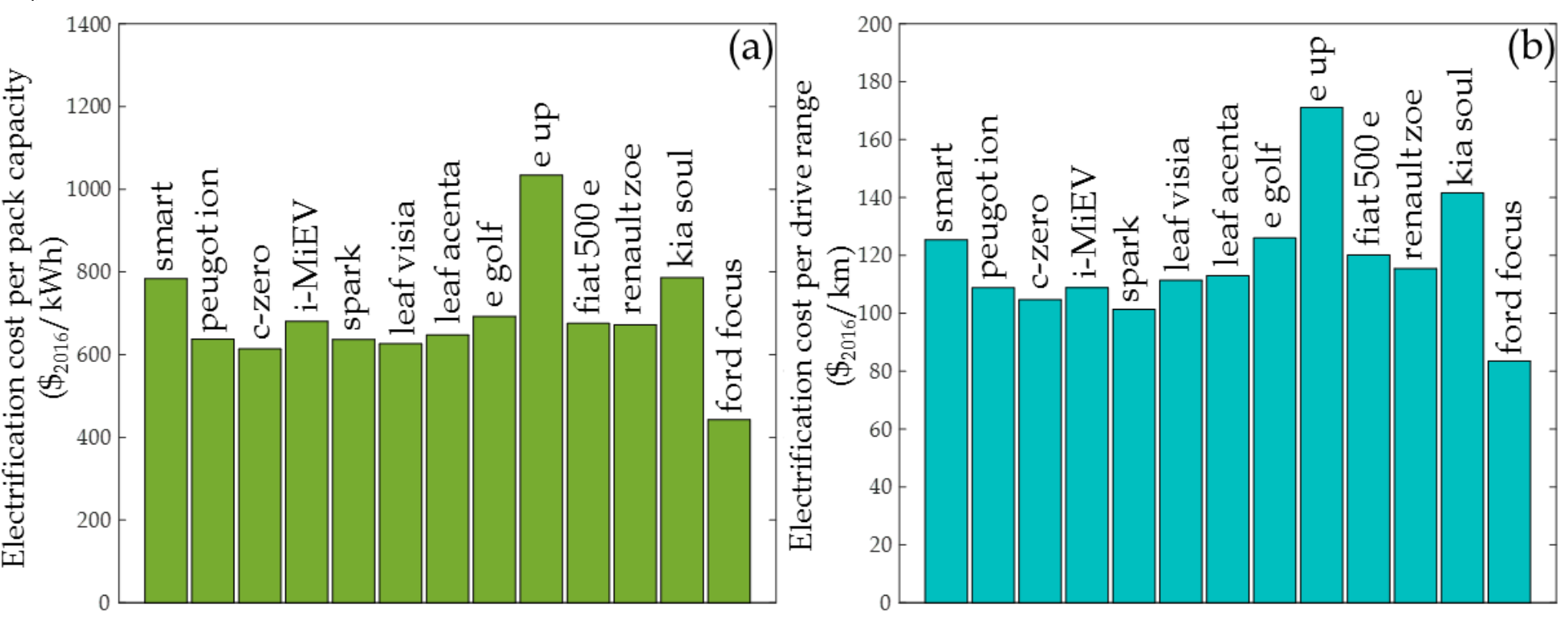


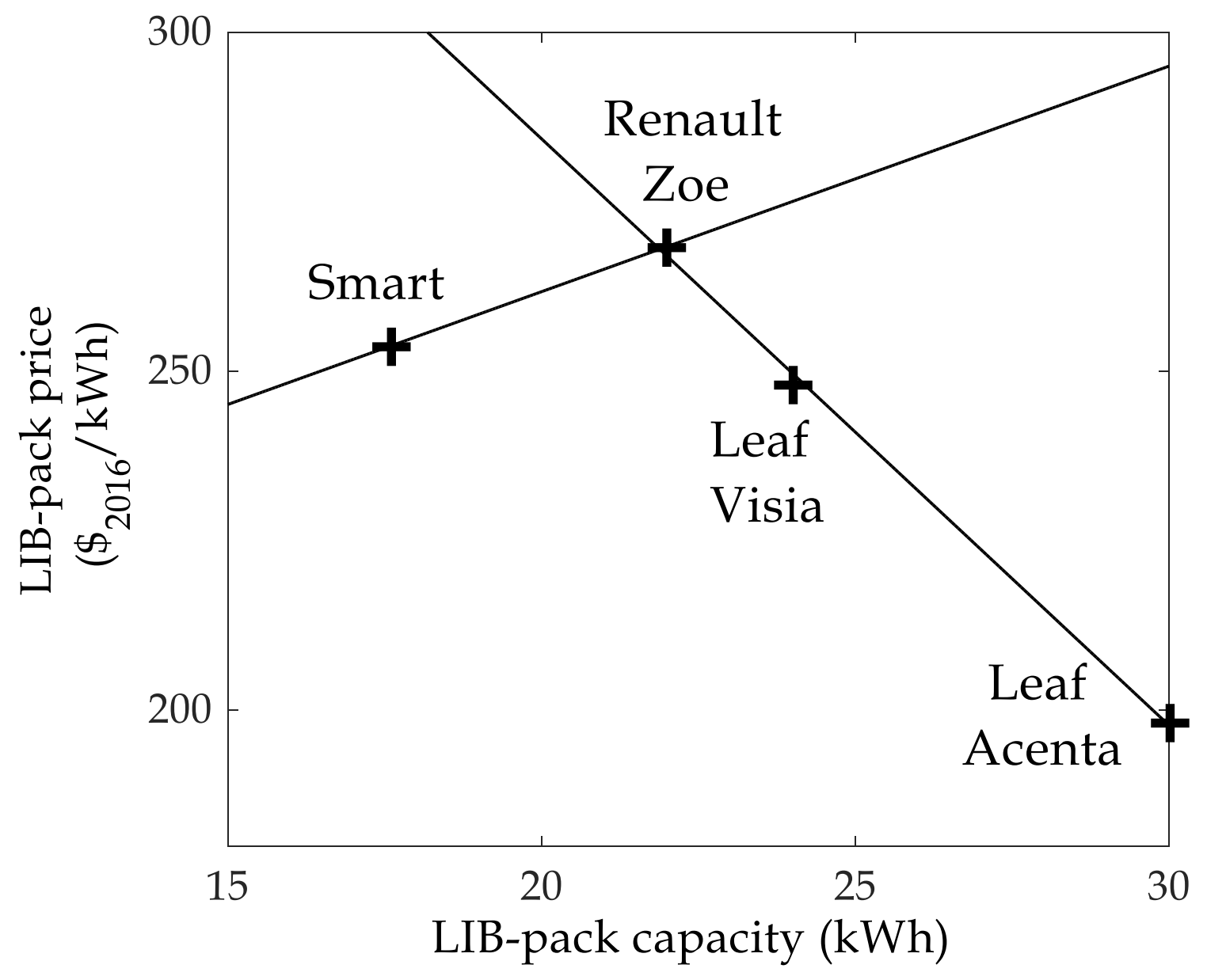

Figure 2. Specific (i.e., per kWh of battery capacity) price of LIB packs in 4 different BEVs with the leasing option for battery pack in 2016 (Table 1). 


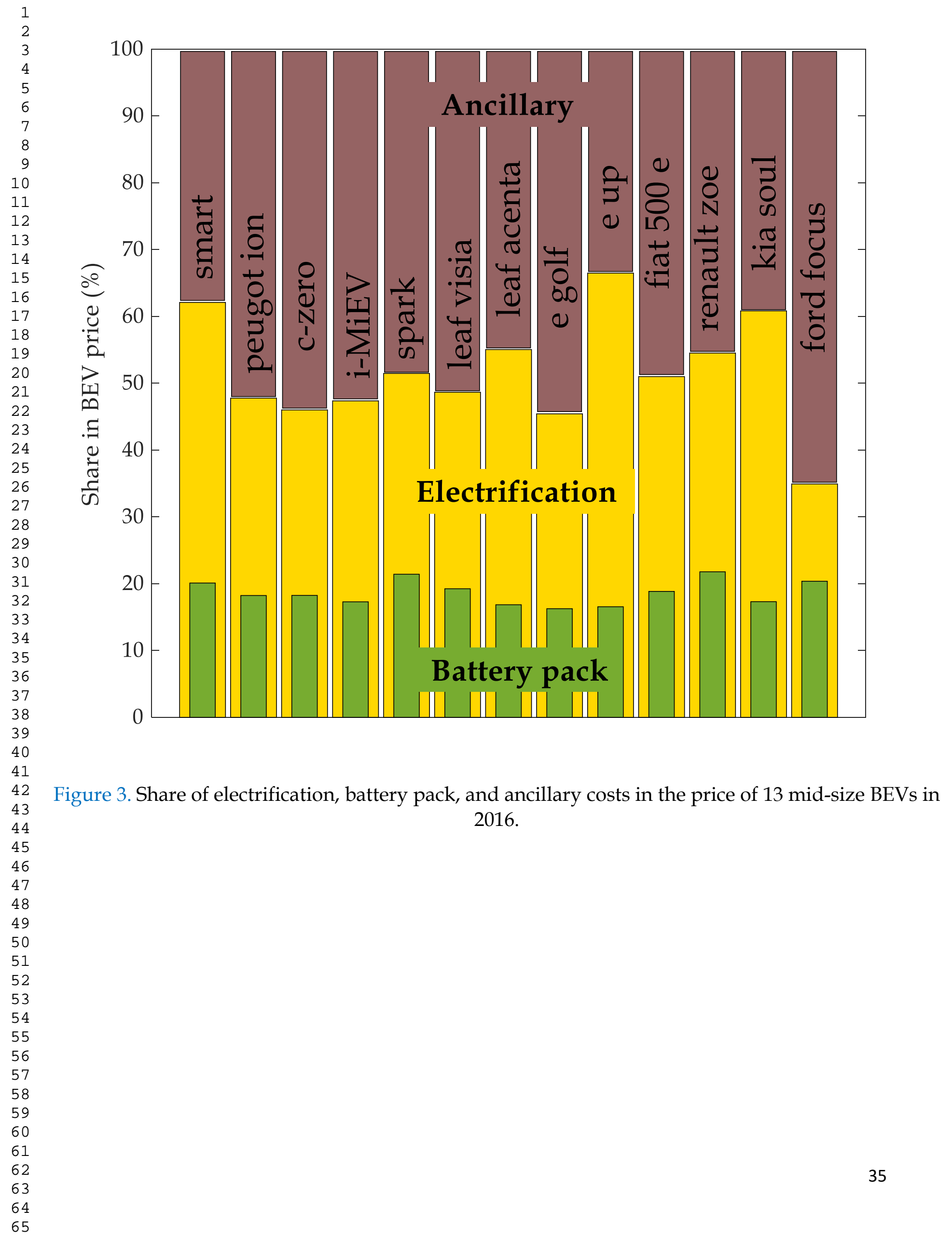




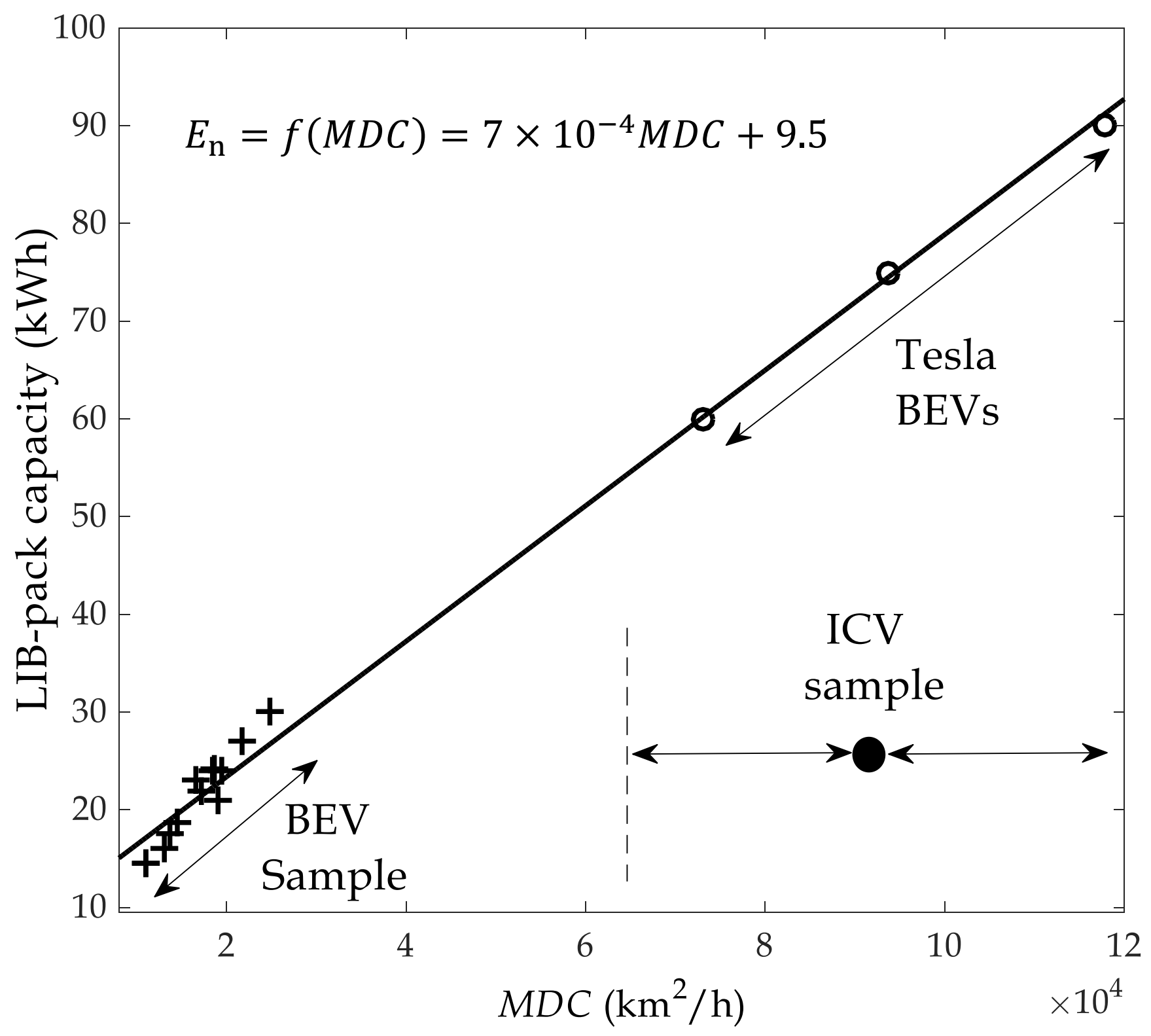

Figure 4. Linear correlation $\left(\mathrm{R}^{2}=0.99\right)$ between the MDC performance index and the capacity of a LIB-pack for the BEV groups considered in this study (+ markers) together with Tesla S (white circles) models. The MDC range and mean (black circle) for the ICV sample is superimposed for comparison. 


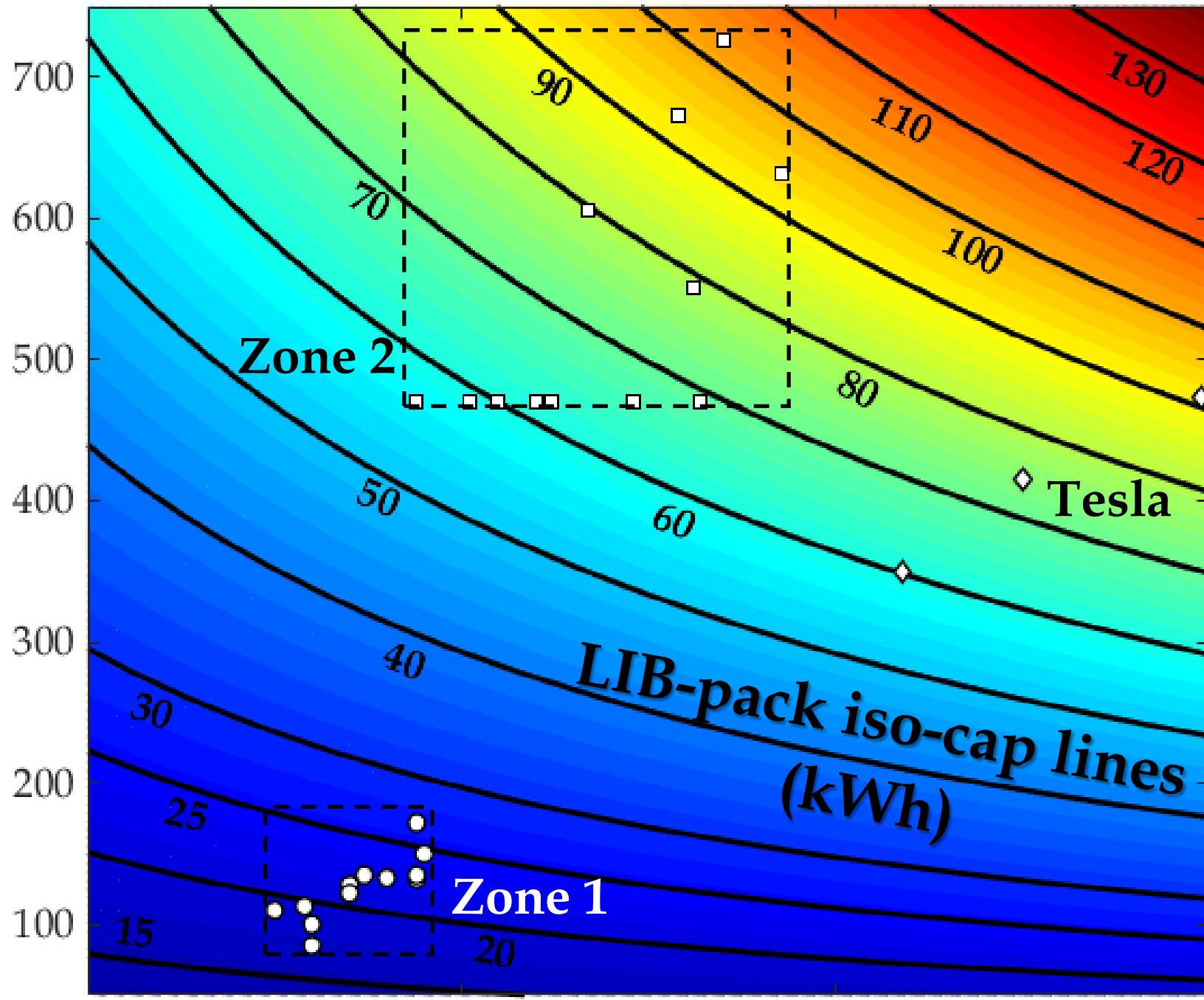

\section{Maximum vehicle speed $(\mathrm{km} / \mathrm{h})$}

Figure 5. An approximate contour plot for the capacity of a LIB battery-pack in a midsize BEV as a function of EPA driving range $(\mathrm{km})$ and maximum speed $(\mathrm{km} / \mathrm{h})$. Black solid lines are the iso-cap lines for the capacity of the current generation of LIB packs, and the MDC coefficients are color coded according to the color-bar. Two rectangular zones (dashed-dotted) define the technical boundaries for the two groups of potential BEV customers, i.e., early adopters (zone 1) and late majority (zone 2). The BEVs (white circles) and ICVs (white squares) from our sample (Table 1), together with Tesla cars (Table A1) (white diamonds), are superimposed on the map for comparison. 

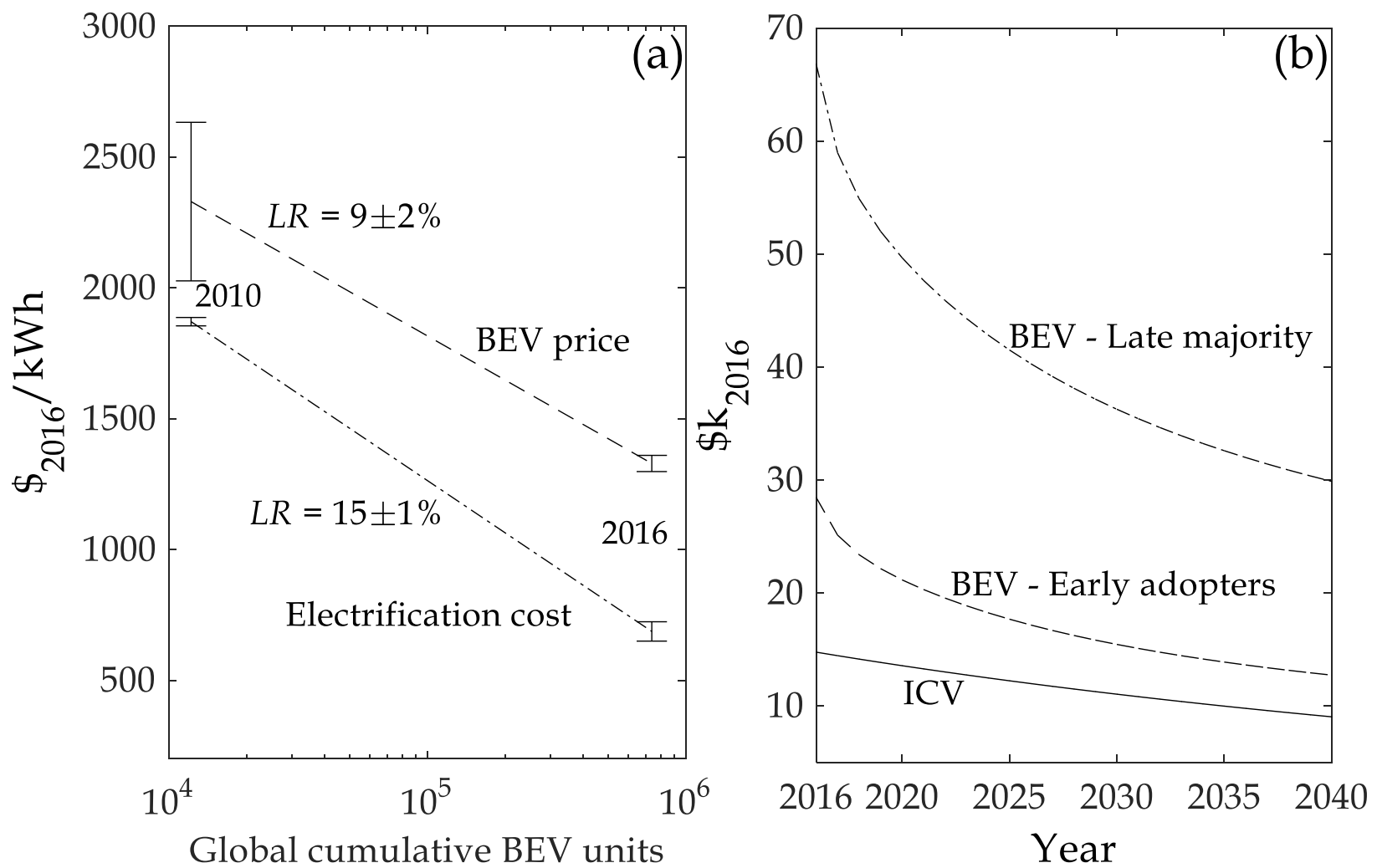

Figure 6. (a) Experience curves for the price and electrification cost of a mid-size BEV over 2010-2016, (b) Projection of price for the mid-size BEV-ICV pairs up to 2040. Two different BEVs (i.e., with different sizes of LIB battery-pack) are considered for 2 groups of BEV customers, i.e., early adopters (dash line) and late majority (dash-dotted). The IEA and IEA2DS projections (OECD/IEA, 2016; Weis et al., 2012) are used for the ICV and BEV stocks, respectively. 

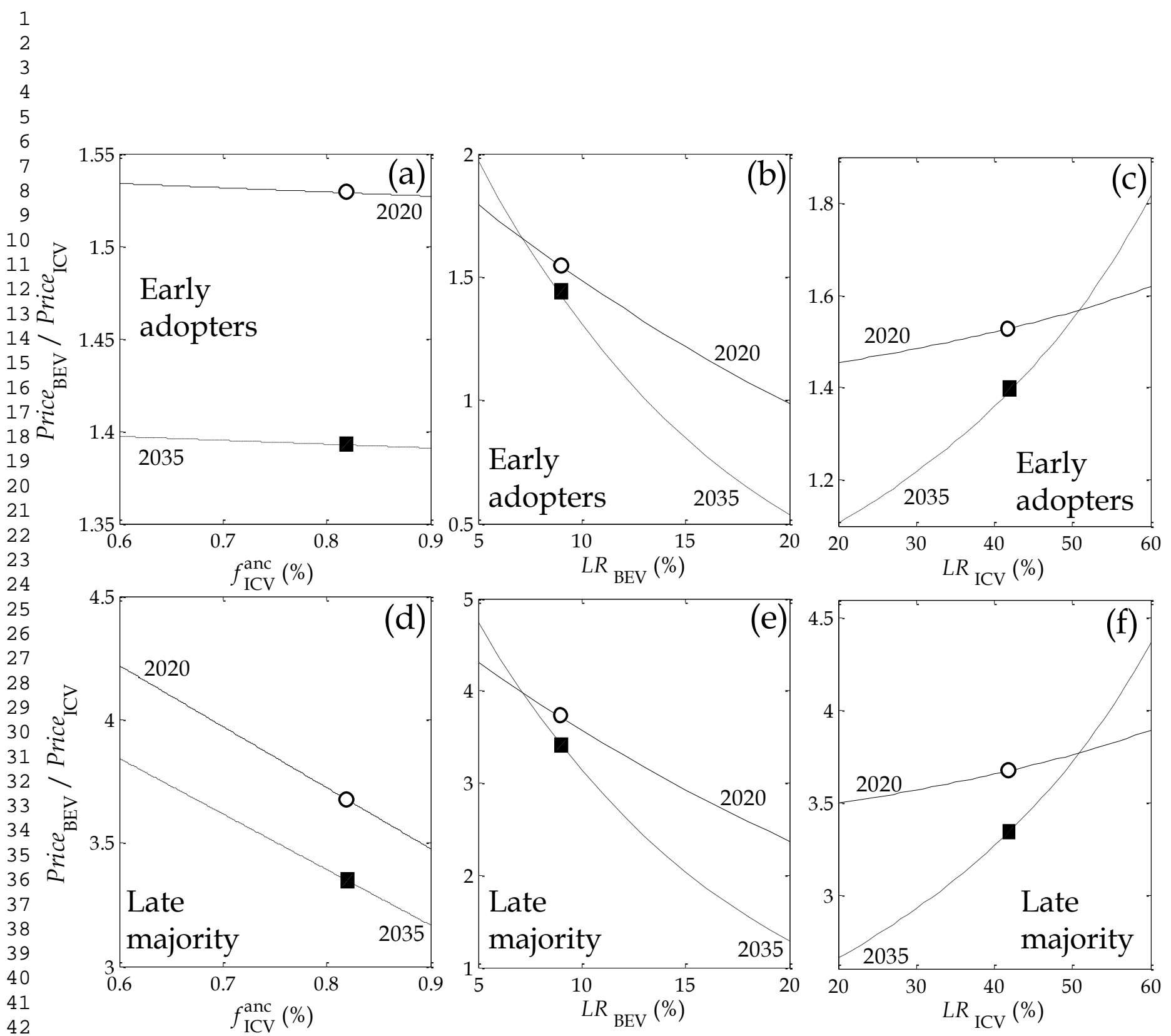

Figure 7. Forecast of price ratio between BEVs and ICVs (Price $\mathrm{BEV} /$ Price $\mathrm{ICV}$ ) for 2020 and 2035 as a function of $(\mathrm{a}, \mathrm{d}) f_{I C V}^{a n c},(\mathrm{~b}, \mathrm{e}) L R_{\mathrm{BEV}}$, and $(\mathrm{c}, \mathrm{f}) L R_{\mathrm{ICV}}$ for two groups of $(\mathrm{a}, \mathrm{b}, \mathrm{c})$ earlyadopters and $(\mathrm{d}, \mathrm{e}, \mathrm{f})$ late-majority. 